\title{
P019: Resistance evaluation of Escherichia coli strains isolated from urines in the urban environment in Benin
}

\author{
L Guedezounme*, M Chodaton, TA Ahoyo, H Bankole \\ From 2nd International Conference on Prevention and Infection Control (ICPIC 2013) \\ Geneva, Switzerland. 25-28 June 2013
}

\section{Introduction}

Antibiotic resistance represents a serious public health problem, particularly in resource limited rcountries. So, it is necessary to have an actualized knowledge about the resistance profile of these microorganisms.

\section{Objectives}

To determine the resistance profile of Escherichia coli strains isolated from urines.

\section{Methods}

This survey assessed 3678 samples of urines received at the national laboratory from 2009 to 2011 . The tests used are urines cytobacteriologic exam and the disk diffusion method.

\section{Results}

In total, 928 Enterobacteriaceae strains were isolated including $52.1 \%$ of $E$. coli, followed by Klebsiella pneumoniae (14\%) and Proteus mirabilis (8.1\%). E. coli occurred more frequently in women (75\%). The antimicrobial susceptibility of $E$. coli shown that the highest rate of resistance was manifested against Amoxicillin (69\%), then followed Amoxicillin + clavulanic Acid (51.1\%), Tetracyclin (45.1\%), Triméthoprim-sulfamethoxazole (42\%), and nalidixic acid (35\%), Ciprofloxacin (23.5\%), Chloramphenicol (22.1\%), Gentamicin (8.1\%), and Ceftriaxon (5.1\%). Multiresistance concerned $32 \%$ of tested strains.

\section{Conclusion}

E. coli strains tested have developed more resistances against commonly prescribed antibiotics in clinical

GBH / EPAC, University of Abomey-Calavi, Abomey, Benin practice in Benin, which is not likely to facilitate the appropriate treatment of patients.

\section{Disclosure of interest}

None declared.

Published: 20 June 2013

\section{doi:10.1186/2047-2994-2-S1-P19}

Cite this article as: Guedezounme et al:: P019: Resistance evaluation of Escherichia coli strains isolated from urines in the urban environment in Benin. Antimicrobial Resistance and Infection Control 2013 2(Suppl 1):P19.
Submit your next manuscript to BioMed Central and take full advantage of:

- Convenient online submission

- Thorough peer review

- No space constraints or color figure charges

- Immediate publication on acceptance

- Inclusion in PubMed, CAS, Scopus and Google Scholar

- Research which is freely available for redistribution

Submit your manuscript at www.biomedcentral.com/submit
() Biomed Central

\section{() Biomed Central}

